THE LONDON SCHOOL

OF ECONOMICS AND

POLITICAL SCIENCE

No: $215 / 2015$

\title{
Geography and Assimilation: A case study of Irish immigrants in late nineteenth century America
}

\author{
Peter Cirenza \\ London School of Economics
}




\title{
LONDON SCHOOL OF ECONOMICS AND POLITICAL SCIENCE \\ DEPARTMENT OF ECONOMIC HISTORY \\ WORKING PAPERS
}

NO. 215- FEBRUARY 2015

\section{Geography and Assimilation: A case study of Irish immigrants in late nineteenth century America}

\author{
Peter Cirenza \\ London School of Economics
}

\begin{abstract}
This paper uses empirical evidence drawn from newly constructed datasets to assess the impact of geographic clustering on the assimilation and occupational mobility of Irish immigrants in the United States in the late nineteenth century. It finds that geographic clustering was quite pronounced for Irish immigrants in this time period. Irish immigrants were primarily drawn to the large metropolitan areas of the Northeast, reflecting the importance of these areas as points of entry to the US, areas of prior settlement by previous generations of Irish immigrants, as well as major centres for employment for new immigrants. This paper also finds that higher levels of geographic clustering were associated with both lower degrees of assimilation and lower occupational outcomes. The benefits of geographic clustering in the job market often described in this literature do not appear to have existed for Irish immigrants in the late nineteenth century. These results would also support the view that living in a more ethnically concentrated community, though perhaps improving the initial starting position of Irish immigrants in America, may have come at the expense of slower subsequent assimilation and reduced occupational mobility.
\end{abstract}

Keywords: International migration, Geographic Mobility, Immigrant, Immigrant Labour, Immigration, Economic History

JEL Codes: F22, J60, N30, N31

Acknowledgements: I wish to thank Chris Minns, Mary Morgan, Dudley Baines, Tim Hatton, participants at the Economic History seminar at the London School of Economics, participants at the Social Science History Association meeting in Chicago, and participants at the "Migration and Integration: Global and Local Dimensions" Conference hosted by Stanford University and the University of Vienna for their support and comments. 


\section{Introduction}

Do ethnic enclaves accelerate or delay the assimilation of immigrants into their new society? And do they enhance the occupational mobility of immigrant groups? This paper assesses the impact of geographic clustering on the degree of assimilation achieved by Irish immigrants in the US in the late nineteenth century. By geographic clustering, I refer to the decision by an Irish immigrant to live in an area which contained a relatively large percentage of Irish immigrants.

In the literature on immigrant assimilation, there is much debate regarding these issues. Economists and sociologists such as Chiswick (2002), Borjas (1999) and Light and Isralowitz (1996) have argued that geographic clustering delays immigrant assimilation. Borjas (1999) found that this was particularly true in cases where the human capital of an ethnic group is lower than that of the host society. ${ }^{1}$ However, there is a literature on late nineteenth century Irish immigrants which argues that the networking opportunities and support systems which had developed in cities with large concentrations of Irish immigrants aided these immigrants in finding work and successfully settling into American life. McCaffrey (1996) argues that the Irish were able to make advances in local government, trade unions and the Catholic Church, and that "employment connected to politics" in particular "provided a base of confidence that eventually launched the Irish into the middle class.”2 McKivigan and Robertson (1996) argue that the Irish in New York City used political connections to entrench themselves "in city government jobs for policemen, firefighters, rapid transit workers and school teachers.” They also argue that by 1900, significant numbers of the city’s Irish had

\footnotetext{
${ }^{1}$ George J. Borjas, Heaven’s Door (Princeton: Princeton University Press, 1999), p. 56.

2 Lawrence J. McCaffrey, “Forging Forward and Looking Back”, in The New York Irish, Ronald H. Bayor and Timothy J, Meagher (eds) (Baltimore: Johns Hopkins University Press, 1996), p.222.
} 
moved up into the ranks of professionals and entrepreneurs.”3 Chiswick (2002) also finds that “immigrant/ethnic concentrations provide information networks that can be very valuable in ... employment activities.”4 Sociologists Portes and Rumbaut (1996) and Gordon (1964) have argued that ethnic enclaves provided significant advantages for new immigrants and immigrant entrepreneurs, and allowed politics to become 'an avenue of individual upward mobility when other paths remain blocked. ${ }^{5}$ Cutler et al. (2008) found that the impact of geographic clustering to be more nuanced, with positive educational and labor market outcomes for some immigrant groups, but negative ones for those with comparatively low levels of education. ${ }^{6}$

This paper utilises sample data on Irish immigrants to assess the impact of geographic clustering on the assimilation and occupational mobility of Irish immigrants in late nineteenth century America. It finds that geographic clustering was quite pronounced for Irish immigrants in late nineteenth century America. Irish immigrants were primarily drawn to the large metropolitan areas of the Northeast, reflecting the importance of these areas as points of entry to the US, areas of prior settlement by previous generations of Irish immigrants, as well as major centres for employment for new immigrants. My analysis also finds that higher levels of geographic clustering were associated with both lower degrees of assimilation and lower occupational outcomes. The benefits of geographic clustering in the job market often described in this literature do not appear to have existed for Irish immigrants in the late nineteenth century. These results also support the view that living in a more ethnically

\footnotetext{
${ }^{3}$ John R. McKivigan and Thomas J. Robertson, 'The Irish American Worker in Transition, 1877-1914” in The New York Irish, Ronald H. Bayor and Timothy J, Meagher (eds) (Baltimore: Johns Hopkins University Press, 1996), p. 312.

${ }^{4}$ Barry R. Chiswick, “Do Enclaves Matter in Immigrant Adjustment?”, Discussion Paper No. 449, The Institute for the Study of Labor (2002), p. 4.

${ }^{5}$ Alejandro Portes and Ruben G. Rumbaut, Immigrant America (Berkeley: 1996), p. 54.

${ }^{6}$ David M. Cutler, Edward L. Glaeser and Jacob L. Vigdor, "When are Ghettos Bad? Lessons from immigrant segregation in the United States”, Journal of Urban Economics 63, 759-774. (2008), p. 772.
} 
concentrated community, though perhaps improving the initial starting position of Irish immigrants in America, may have come at the expense of slower subsequent assimilation and reduced occupational mobility.

\section{Data}

My unit of measurement for this analysis is the county, the primary legal division of states in America and often the most local level of government. Counties are also the smallest unit of measurement for which it is possible to obtain complete US census information for immigrants and the overall population in the late nineteenth century. ${ }^{7}$ I have used the University of Virginia Historical Census Browser ${ }^{8}$ to create a database with the percentage of Irish immigrants living in each county in the US in 1900. The University of Virginia census data is based on a complete sample of the relevant censuses, and thus provides a robust basis for examining the issue of geographic clustering in late nineteenth century America. Separately, I have also created a sample of Irish immigrants who came to the US prior to 1900 using the IPUMS $2.5 \%$ US census sample for $1900^{9}$. This sample is comprised of 26,722 male immigrants between the ages of 25 and 65 years old, who were in the workforce in 1900. In addition to capturing the broad range of socio-economic variables available in US census data, I have also included their county of residence. This sample, when cross referenced with the complete county level data available from the University of Virginia Historical Census Browser, allows me to examine in a robust manner the effect of geographic clustering on the assimilation of Irish immigrants in the late nineteenth century. To assess the influence of previous generations of Irish immigrants on the geographic settlement patterns of

\footnotetext{
${ }^{7}$ Obtaining $100 \%$ of the census sample information is crucial, as a partial sample would not be sufficiently robust for measuring the percentage of Irish immigrants in any given location.

${ }^{8}$ Historical Census Browser. The University of Virginia, Geospatial and Statistical Data Center: http://fisher.lib.virginia.edu/collections/stats/histcensus/index.html. (2004).

${ }^{9}$ Steven Ruggles, J. Trent Alexander, Katie Genadek, Ronald Goeken, Matthew B. Schroeder, and Matthew Sobek. Integrated Public Use Microdata Series: Version 5.0 [Machine-readable database]. Minneapolis: University of Minnesota, 2010.
} 
the Irish immigrants living in America in 1900, I also accessed the University of Virginia Historical Census Browser to determine the percentage of Irish immigrants living in each county in the US in each decade from 1870 until $1900 .^{10}$

\section{Extent of geographic clustering}

The first question to be addressed is to what extent geographic clustering existed for the Irish in late nineteenth century America. Using data from the University of Virginia Historical Census Browser, I have created a map of the US which illustrates the percentage of Irish born residents relative to the total population of each county in the US in 1900. The map in Figure 1 shows each county based on its percentage of Irish immigrants to the total population, and groups the counties into five categories based on this percentage $(0-2.5 \%, 2.5-5 \%, 5-10 \%$, more than $10 \%$, and counties for which there were no data available). As can be seen from Figure 1, there was a significant concentration of Irish immigrants in the Northeastern section of the US in 1900. In and around of the cities of Boston, Providence, New York and Philadelphia were found the highest percentages of Irish immigrants. Regional cities such as Springfield, Hartford and Albany also exhibited relatively high percentages of Irish immigrants. The Chicago metropolitan area had a lower but still prominent percentage of Irish immigrants relative to its total population. In the West, there were also a few counties with a relatively high percentage of Irish immigrants, though the absolute number of Irish was quite limited. Table 1 lists the 25 counties in the US in 1900 that had the highest percentage of Irish immigrants relative to their total populations.

So what conclusions can we draw from this data? First of all, there is clear evidence of geographic clustering of Irish immigrants in this timeframe. The Irish were not evenly spread

\footnotetext{
${ }^{10}$ I would have preferred to have had historical data for periods prior to 1870 , but complete county level data is only available from 1870 onwards.
} 
across the country, but tended to live in certain regions where they constituted a much higher percentage of the overall population. In many sections of the US, the percentage of Irish immigrants was extremely low. For example, in the underlying data there are 2,172 counties where the Irish constituted less than $1 \%$ of the total population. ${ }^{11}$ There were also 379 counties where the Irish constituted less than $.01 \%$ of the total population. With the exception of one county in rural Pennsylvania, all of these 379 counties were located in the Southern and Western regions of the US. What is quite clear from the evidence is that the Irish tended to cluster in or near the major cities of the Northeast. In fact, 22 of the 25 counties with the highest percentage of Irish immigrants in 1900 were located in Northeastern states. Several of the main cities in this region, in particular Boston, New York and Philadelphia, were also leading ports of entry for immigrants coming from Europe in this timeframe. So it would appear that Irish immigrants often settled in locations that were near to where they may have first entered the US. In addition, these cities were also the largest in the US in this time period and thus would have been a logical place for immigrants to seek employment. Finally, it is also striking that some Irish immigrants were willing to travel clear across the vast heartland of the US to find work in frontier areas in the West. In counties such as Storey, Nevada, and Silver Bow and Deer Lodge in the state of Montana, mining jobs drew Irish immigrants to live and work in these remote, sparsely populated areas of the US.

\footnotetext{
${ }^{11}$ To put this number in perspective, there were only 2771 counties listed in the University of Virginia Historical Census Browser for 1900.
} 
Figure 1

\section{Percentage Irish by county in the United States in 1900}

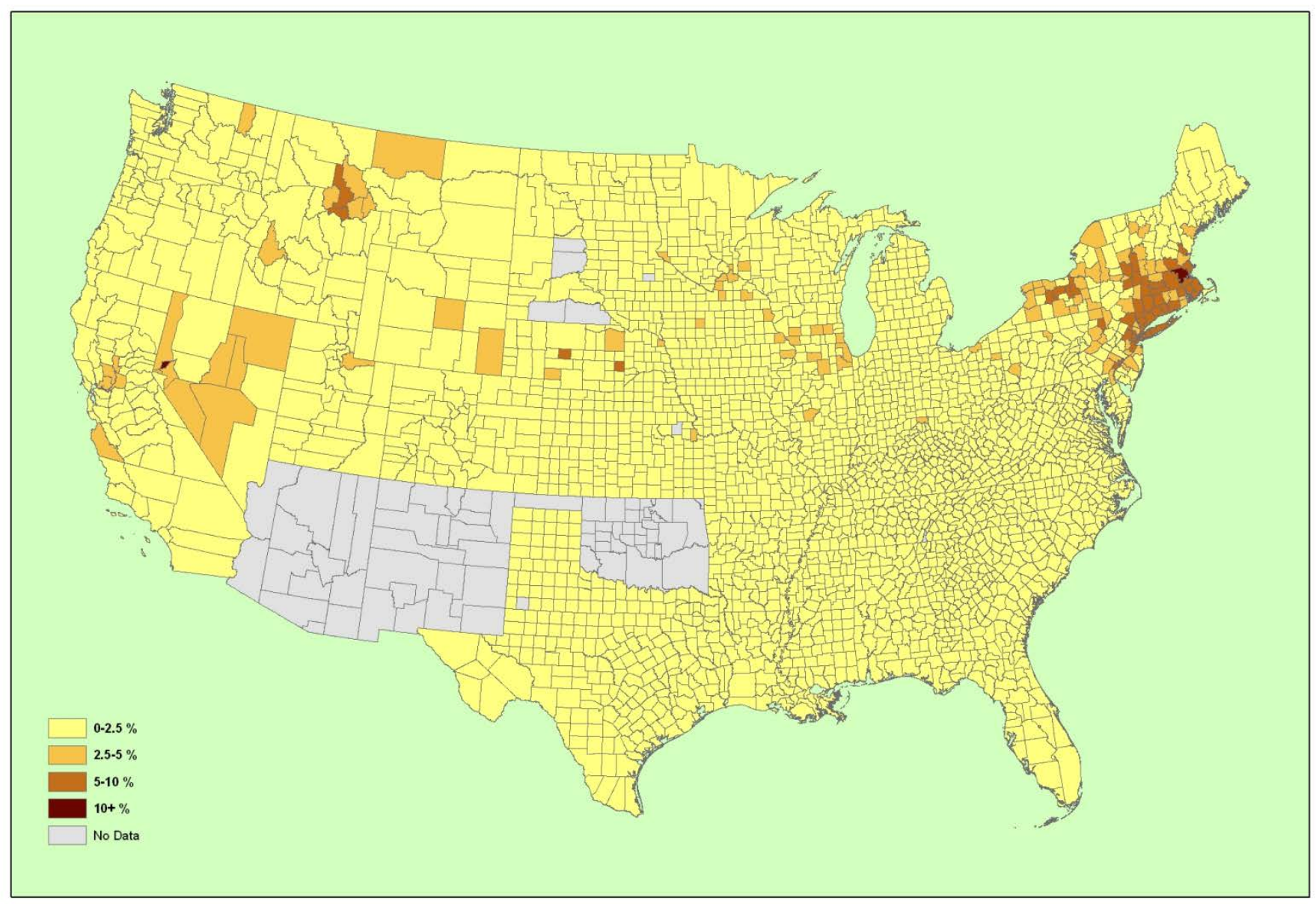


Table 1

Top 25 Counties Ranked by Percentage of Irish-born Population in 1900

$\begin{array}{lllrc}\text { County } & \text { State } & \text { Description } & \begin{array}{r}\text { Number of } \\ \text { Irish-born }\end{array} & \begin{array}{c}\text { \% } \\ \text { Irish- } \\ \text { born }\end{array} \\ \text { Suffolk } & \text { Massachusetts } & \text { Boston metropolitan area } & 73,501 & 12.02 \% \\ \text { Storey } & \text { Nevada } & \text { Mining region } & 400 & 10.89 \\ \text { Middlesex } & \text { Massachusetts } & \text { Boston metropolitan area } & 57,496 & 10.16 \\ \text { Norfolk } & \text { Massachusetts } & \text { Boston metropolitan area } & 14,716 & 9.71 \\ \text { Silver Bow } & \text { Montana } & \text { Mining region } & 4,582 & 9.62 \\ \text { New Haven } & \text { Connecticut } & \text { New York metropolitan area } & 24,666 & 9.16 \\ \text { Newport } & \text { Rhode Island } & \text { Providence metropolitan area } & 2,962 & 9.09 \\ \text { Providence } & \text { Rhode Island } & \text { Regional city } & 29,740 & 9.05 \\ \text { Hampden } & \text { Massachusetts } & \text { Springfield metropolitan area } & 15,891 & 9.05 \\ \text { New York } & \text { New York } & \text { New York metropolitan area } & 178,886 & 8.72 \\ \text { Hartford } & \text { Connecticut } & \text { Regional city } & 17,044 & 8.72 \\ \text { Westchester } & \text { New York } & \text { New York metropolitan area } & 16,047 & 8.71 \\ \text { Rensselaer } & \text { New York } & \text { Albany metropolitan area } & 10,389 & 8.54 \\ \text { Hudson } & \text { New Jersey } & \text { New York metropolitan area } & 31,225 & 8.09 \\ \text { Deer Lodge } & \text { Montana } & \text { Mining region } & 1,295 & 8.02 \\ \text { Fairfield } & \text { Connecticut } & \text { New York metropolitan area } & 14,348 & 7.79 \\ \text { Worcester } & \text { Massachusetts } & \text { Regional city } & 26,873 & 7.75 \\ \text { Essex } & \text { Massachusetts } & \text { Boston metropolitan area } & 27,488 & 7.70 \\ \text { Philadelphia } & \text { Pennsylvania } & \text { Philadelphia metropolitan area } & 98,427 & 7.61 \\ \text { Richmond } & \text { New York } & \text { New York metropolitan area } & 4,858 & 7.25 \\ \text { Kings } & \text { New York } & \text { New York metropolitan area } & 83,400 & 7.15 \\ \text { Bristol } & \text { Rhode Island } & \text { Providence metropolitan area } & 898 & 6.83 \\ \text { Hampshire } & \text { Massachusetts } & \text { Springfield metropolitan area } & 3,970 & 6.75 \\ \text { Union } & \text { New Jersey } & \text { New York metropolitan area } & 6,610 & 6.65 \\ \text { New London } & \text { Connecticut } & \text { Regional city } & 5,506 & 6.65 \\ & & & & \end{array}$


To what extent were Irish immigrants drawn to areas where earlier generations of Irish immigrants had also settled after arriving in the US? Using the University of Virginia Historical Census Browser, I have created maps of the US which illustrate the percentage of Irish born residents relative to the total population of each county in the US in each of 1870, 1880 and 1890, in addition to 1900. These maps group the counties into six categories based on the percentage of Irish immigrants to the total population $(0-2.5 \%, 2.5-5 \%, 5-10 \%, 10-$ $15 \%$ and more than $15 \%$, and counties for which there were no data available). As these maps illustrate, there is a clear pattern of settlement of Irish immigrants in the major metropolitan areas of the Northeast as far back as 1870 which is very similar to the settlement patterns we observed for Irish immigrants in 1900. In 1870, in addition to the major metropolitan areas in the Northeast, Midwestern cities such as Chicago and Western counties in states including Nebraska, Minnesota and California also had high percentages of Irish immigrants in their populations. In terms of the absolute numbers, the New York and Boston metropolitan areas were much more significant than any other regions in the analysis (as they continue to be in 1900). The maps for 1880, 1890 and 1900 illustrate the continued importance of the major metropolitan areas of the Northeast, coupled with a decline in the number of Midwestern and Western counties with very high percentages of Irish immigrants. There are several likely reasons for this trend. Whereas Irish immigrants were the dominant immigrant group in the decades following 1850, other immigrant groups from Southern and Eastern Europe were becoming more important as the twentieth century approached. In addition, these maps only capture first generation Irish immigrants, and do not show the presence of second and third generation Irish immigrants who also would have been a very sizeable presence in these communities. Finally, general population growth would also contribute to a reduction in the percentage of Irish immigrants in the US over this time period. 
Figure 2

\section{Percentage Irish by county in the United States in 1870}

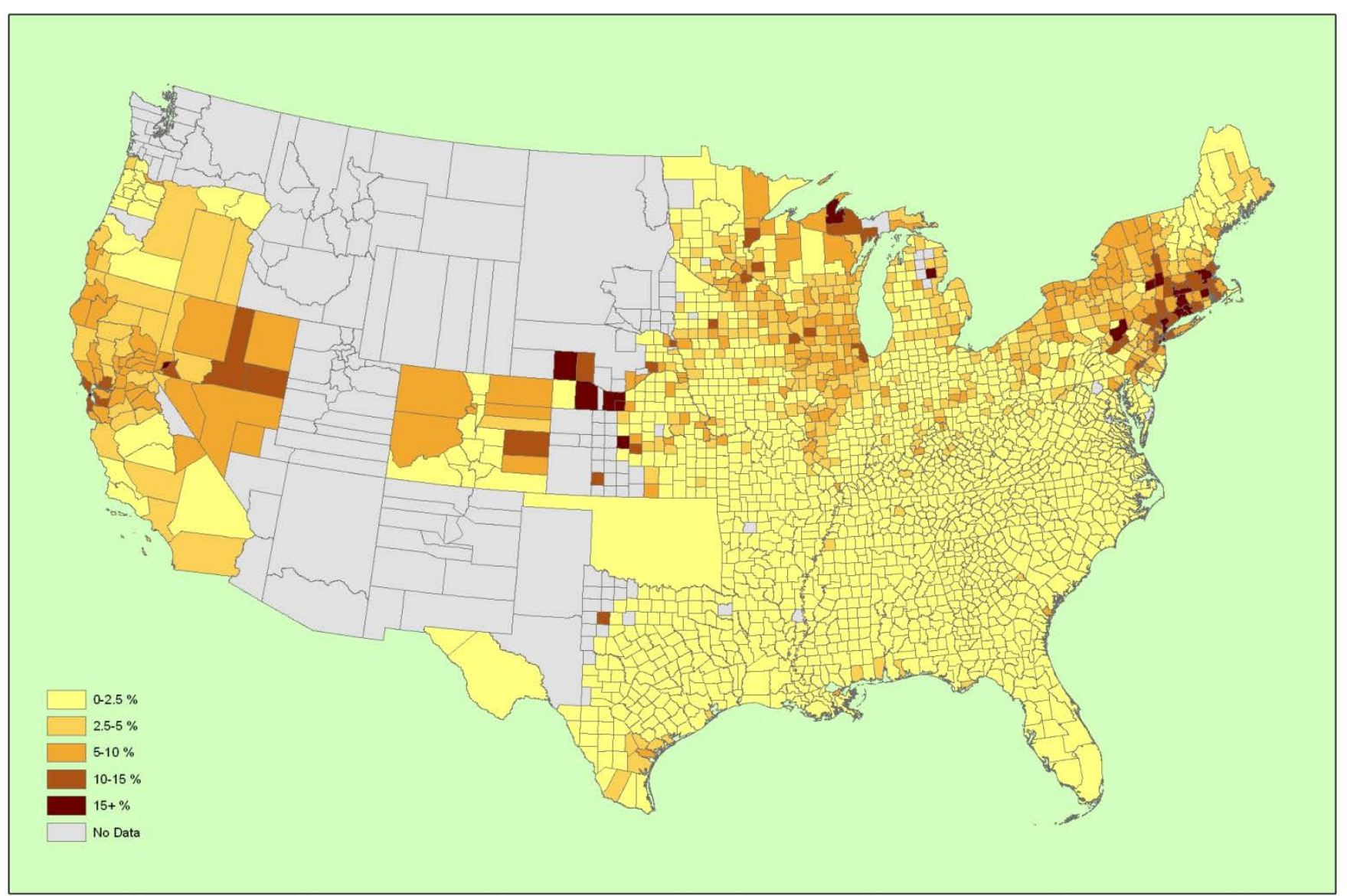


Figure 3

\section{Percentage Irish by county in the United States in 1880}

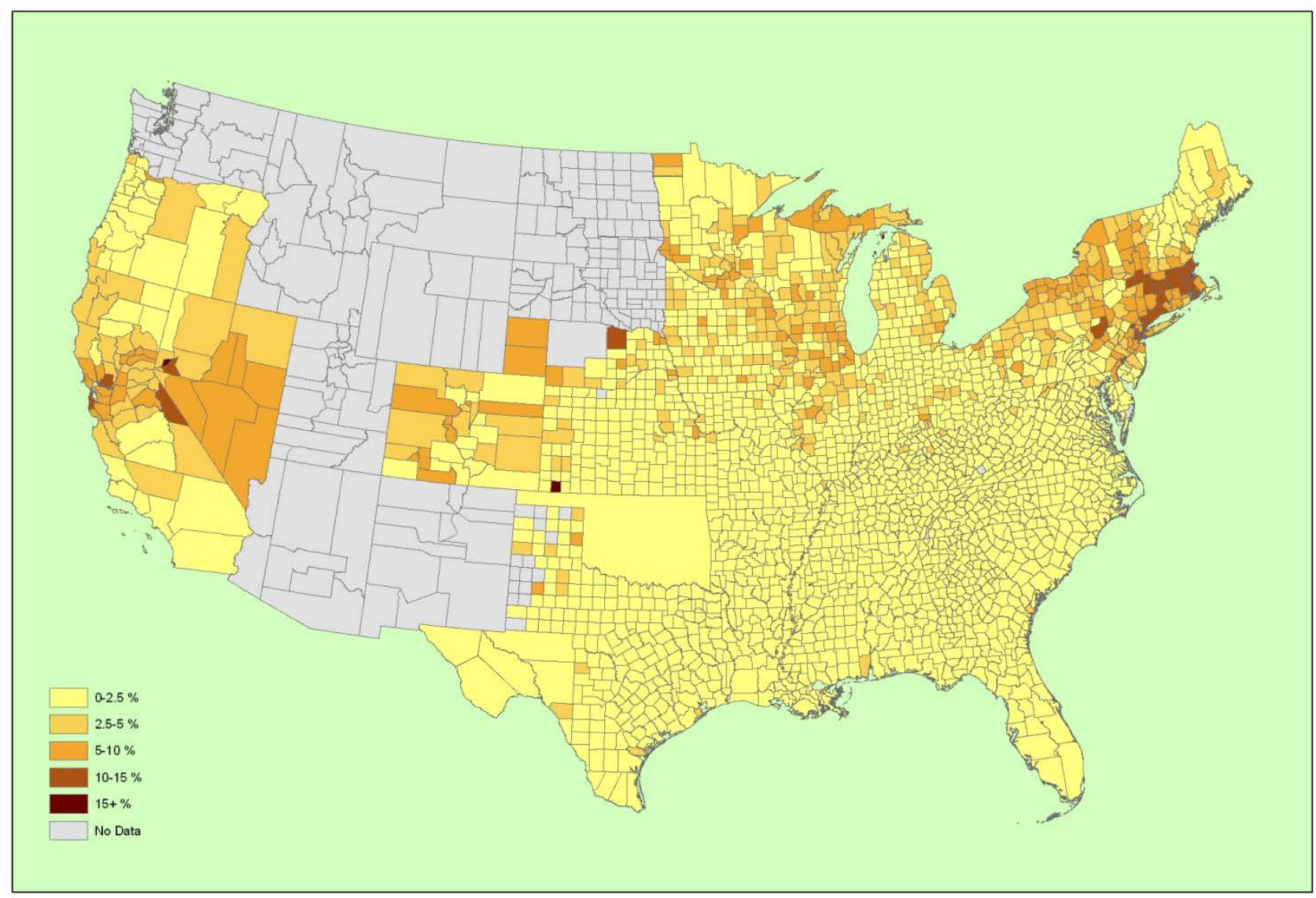


Figure 4

\section{Percentage Irish by county in the United States in 1890}

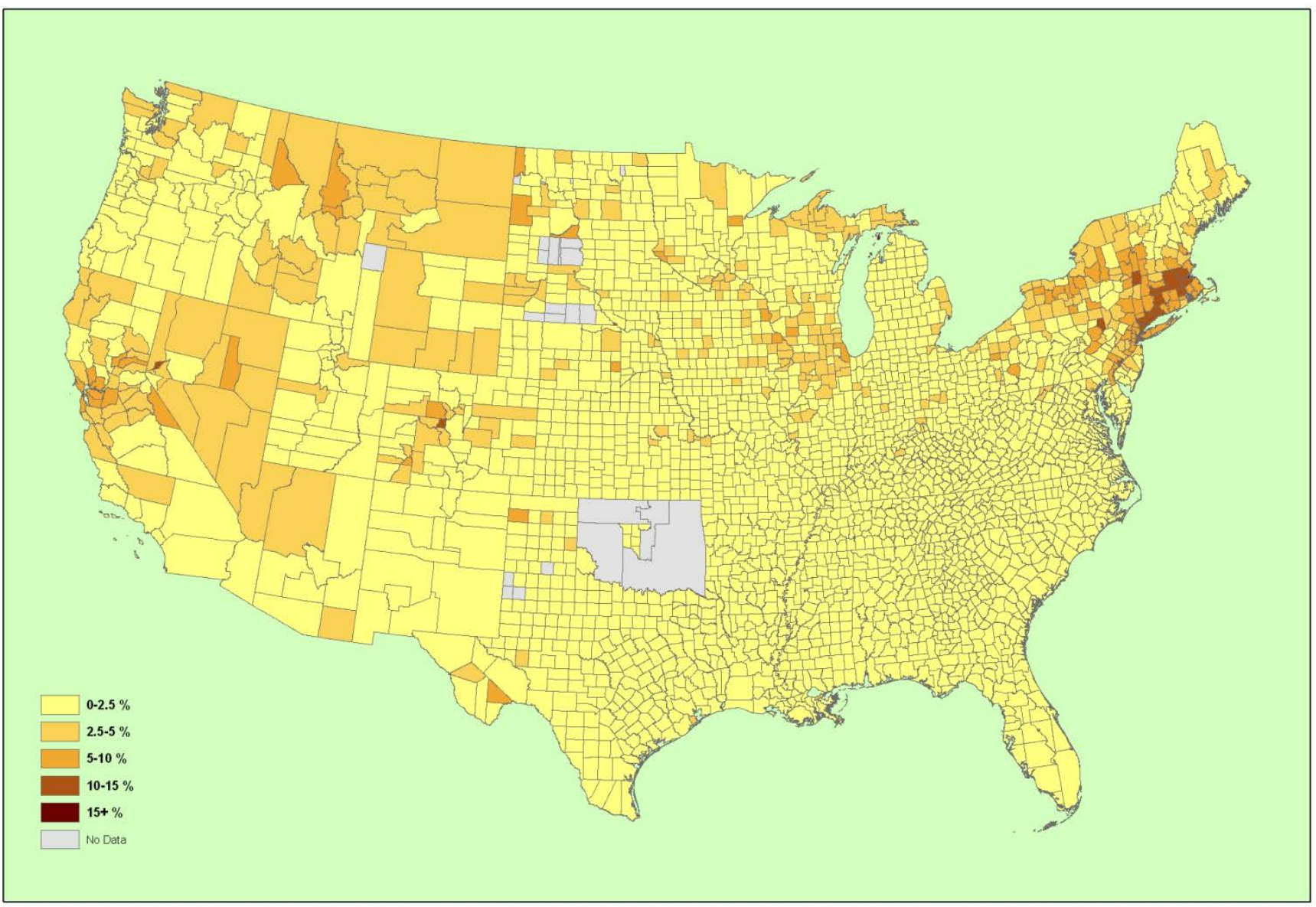


Figure 5

\section{Percentage Irish by county in the United States in 1900}

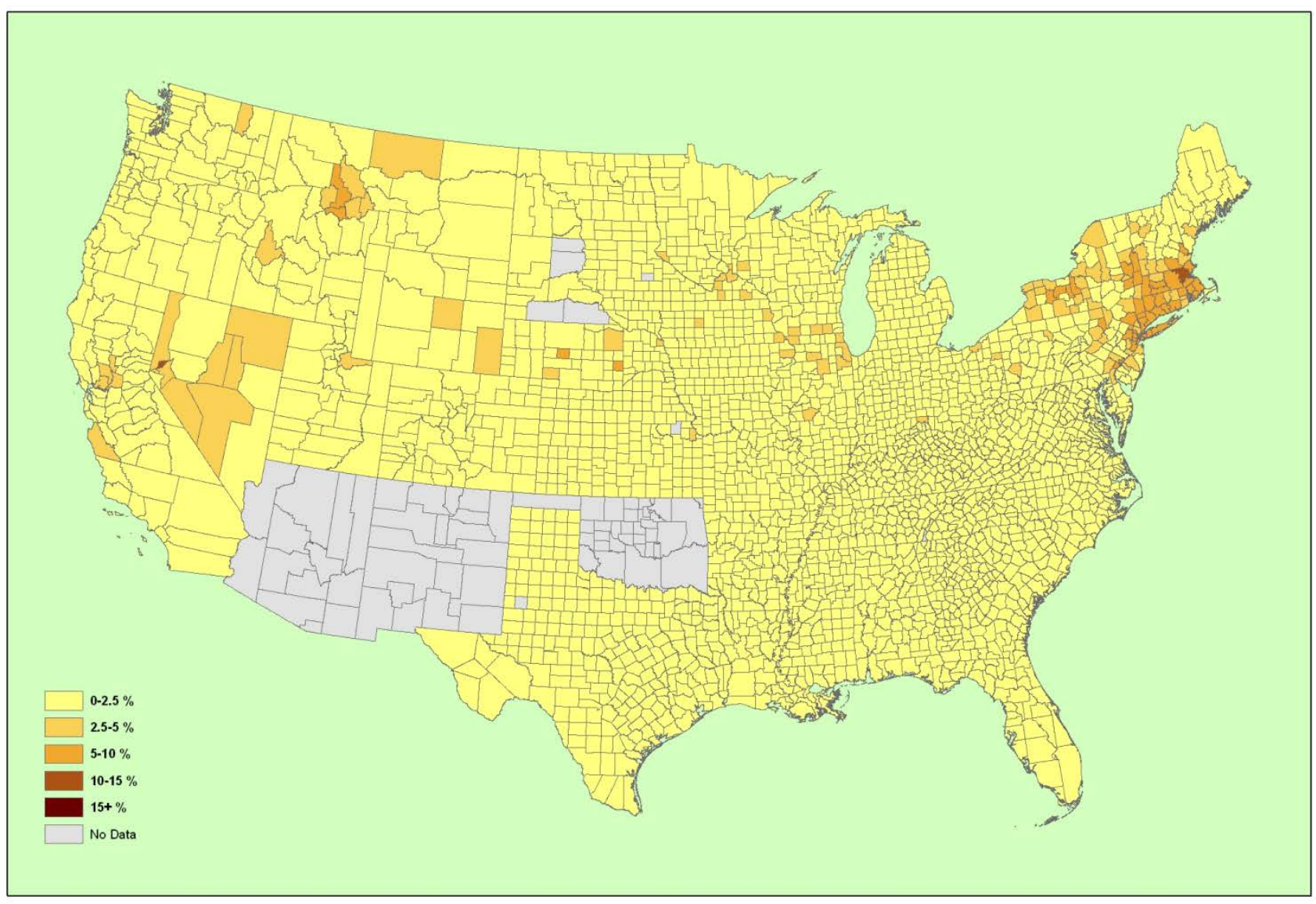


It is also useful to place the Irish experience in the context of other prominent immigrant groups in this timeframe. The two other leading European immigrant groups in the US in the late nineteenth century were the English and the Germans. For this analysis, I have also included the Scottish, perhaps the immigrant group most similar to the Irish. As can be seen from the Tables 2, 3 and 4, the most clustered areas where German, English and Scottish immigrants chose to live looked quite different from those chosen by the Irish. Whereas the Irish were most likely to cluster in and around the major cities of the Northeast, with smaller numbers willing to venture out to the West in search of employment primarily in the mining industry, none of the other immigrant groups in this comparison had a similar experience. The Germans, who were the largest European immigrant group in the US in this timeframe, were much more likely to congregate in the Midwest, in particular in the states of Wisconsin, Iowa and Minnesota, where farming was the primary occupation. None of the 25 counties where the German clustering levels were highest were in the East. As for the English and Scottish, these British groups were more likely to cluster in high percentages in the West, primarily in mining regions. They were not as well represented in the Eastern parts of the country as were the Irish. And for the Eastern counties that were among the highest in clustering levels for the English and Scottish, few were in and around the urban centres of New York, Boston and Philadelphia. These immigrant groups, in particular the English and Scottish, did resemble the Irish in that in many parts of the US, the percentage of these immigrants in the population was quite low. The Germans were somewhat less concentrated, settling in larger percentages in more counties throughout the US than did the other groups. In this respect, the Germans more closely resembled the native born. 
Table 2

Top 25 Counties Ranked by Percentage of German-born Population in 1900

$\begin{array}{llcl}\text { County } & \text { State } & \begin{array}{c}\text { Number of } \\ \text { German-born }\end{array} & \begin{array}{c}\mathbf{\%} \\ \text { German-born }\end{array} \\ \text { Taylor } & \text { Wisconsin } & 2,462 & 21.86 \% \\ \text { Marathon } & \text { Wisconsin } & 8,712 & 20.14 \\ \text { Sheboygan } & \text { Wisconsin } & 10,067 & 20.00 \\ \text { Milwaukee } & \text { Wisconsin } & 63,952 & 19.38 \\ \text { Jefferson } & \text { Wisconsin } & 6,739 & 19.37 \\ \text { Dodge } & \text { Wisconsin } & 8,868 & 19.02 \\ \text { Carver } & \text { Minnesota } & 3,198 & 18.23 \\ \text { Ozaukee } & \text { Wisconsin } & 2,972 & 18.16 \\ \text { Scott } & \text { Iowa } & 9,234 & 17.91 \\ \text { Cuming } & \text { Nebraska } & 2,571 & 17.63 \\ \text { Green Lake } & \text { Wisconsin } & 2,705 & 17.12 \\ \text { Washington } & \text { Wisconsin } & 3,984 & 16.89 \\ \text { Brown } & \text { Minnesota } & 3,326 & 16.81 \\ \text { Grundy } & \text { Iowa } & 2,280 & 16.57 \\ \text { Shawano } & \text { Wisconsin } & 4,524 & 16.47 \\ \text { Calumet } & \text { Wisconsin } & 2,738 & 16.03 \\ \text { Crawford } & \text { Iowa } & 3,436 & 15.85 \\ \text { Ottawa } & \text { Ohio } & 3,515 & 15.82 \\ \text { Du Page } & \text { Illinois } & 4,418 & 15.67 \\ \text { Douglas } & \text { Nevada } & 240 & 15.65 \\ \text { Sibley } & \text { Minnesota } & 2,634 & 15.62 \\ \text { Lincoln } & \text { Wisconsin } & 2,526 & 15.53 \\ \text { Outagamie } & \text { Wisconsin } & 6,786 & 14.67 \\ \text { Marquette } & \text { Wisconsin } & 1,506 & 14.33 \\ \text { Winnebago } & \text { Wisconsin } & 8,299 & 14.25 \\ & & & \end{array}$


Table 3

Top 25 Counties Ranked by Percentage of English-born Population in 1900

$\begin{array}{ll}\text { County } & \text { State } \\ \text { Bailey } & \text { Texas } \\ \text { Davis } & \text { Utah } \\ \text { Salt Lake } & \text { Utah } \\ \text { Summit } & \text { Utah } \\ \text { Bristol } & \text { Massachusetts } \\ \text { Beaver } & \text { Utah } \\ \text { Morgan } & \text { Utah } \\ \text { Juab } & \text { Utah } \\ \text { Rich } & \text { Utah } \\ \text { Weber } & \text { Utah } \\ \text { Owyhee } & \text { Idaho } \\ \text { Silver Bow } & \text { Montana } \\ \text { Tooele } & \text { Utah } \\ \text { Marquette } & \text { Michigan } \\ \text { Iron } & \text { Utah } \\ \text { Utah } & \text { Utah } \\ \text { Uinta } & \text { Wyoming } \\ \text { Granite } & \text { Montana } \\ \text { Eureka } & \text { Nevada } \\ \text { Cache } & \text { Utah } \\ \text { Houghton } & \text { Michigan } \\ \text { Storey } & \text { Nevada } \\ \text { Hansford } & \text { Texas } \\ \text { Providence } & \text { Rhode Island } \\ \text { Bear Lake } & \text { Idaho } \\ & \end{array}$

\author{
Number of $\quad \%$ \\ English-born English-born
}

$\begin{array}{lc}1 & 25.00 \% \\ 838 & 10.48 \\ 7,130 & 9.17 \\ 859 & 9.10 \\ 20,584 & 8.17 \\ 295 & 8.16 \\ 166 & 8.12 \\ 816 & 8.09 \\ 154 & 7.91 \\ 1,942 & 7.69 \\ 289 & 7.60 \\ 3,555 & 7.46 \\ 541 & 7.35 \\ 3,020 & 7.32 \\ 255 & 7.19 \\ 2,205 & 6.79 \\ 815 & 6.67 \\ 281 & 6.49 \\ 123 & 6.29 \\ 1,088 & 6.00 \\ 3,955 & 5.99 \\ 220 & 5.99 \\ 10 & 5.99 \\ 19,624 & 5.97 \\ 419 & 5.94\end{array}$


Table 4

Top 25 Counties Ranked by Percentage of Scottish-born Population in 1900

$\begin{array}{llcc}\text { County } & \text { State } & \begin{array}{c}\text { Number of } \\ \text { Scottish-born }\end{array} & \begin{array}{c}\text { \% } \\ \text { Scottish-born }\end{array} \\ \text { Sweetwater } & \text { Wyoming } & 291 & 3.44 \% \\ \text { Washington } & \text { Vermont } & 1,189 & 3.25 \\ \text { Uinta } & \text { Wyoming } & 359 & 2.94 \\ \text { Grundy } & \text { Illinois } & 698 & 2.89 \\ \text { Meagher } & \text { Montana } & 63 & 2.49 \\ \text { Wasatch } & \text { Utah } & 116 & 2.45 \\ \text { Carbon } & \text { Utah } & 113 & 2.26 \\ \text { Passaic } & \text { New Jersey } & 3,401 & 2.19 \\ \text { Carbon } & \text { Montana } & 160 & 2.12 \\ \text { Fergus } & \text { Montana } & 147 & 2.12 \\ \text { Park } & \text { Montana } & 155 & 2.11 \\ \text { Washington } & \text { Rhode Island } & 505 & 2.09 \\ \text { Terry } & \text { Texas } & 1 & 2.08 \\ \text { Allegany } & \text { Maryland } & 1,093 & 2.04 \\ \text { Natrona } & \text { Wyoming } & 36 & 2.02 \\ \text { Rich } & \text { Utah } & 38 & 1.95 \\ \text { Fresno } & \text { California } & 734 & 1.94 \\ \text { Hooker } & \text { Nebraska } & 8 & 1.85 \\ \text { Tooele } & \text { Utah } & 131 & 1.78 \\ \text { Glasscock } & \text { Texas } & 5 & 1.75 \\ \text { Jefferson } & \text { Pennsylvania } & 985 & 1.67 \\ \text { Summit } & \text { Utah } & 154 & 1.63 \\ \text { Cascade } & \text { Montana } & 395 & 1.53 \\ \text { Bottineau } & \text { North Dakota } & 114 & 1.51 \\ \text { Salt Lake } & \text { Utah } & 1,167 & 1.50\end{array}$




\section{Geographic clustering and assimilation}

Table 5 presents summary statistics from my sample of Irish immigrants based on their level of geographic clustering. The table separates the sample into those immigrants who lived in counties with above and below average levels of geographic clustering. The results are striking. The two groups have marked and statistically significant differences in virtually every characteristic under review. Those Irish immigrants who lived in counties with below average levels of Irish immigrants were substantially more rural, more likely to own a home and more likely to have married a non-Irish born spouse. In addition, their spouses had lower levels of infant mortality and were less likely to be in the workforce. In all these respects, these Irish immigrants more closely resembled the native born sample. Only in the area of literacy did the above average clustered Irish more closely resemble the native born, and in this instance the difference, though statistically significant, is not very meaningful as more than nine out of ten of both groups were classified as literate in the 1900 US census.

One possible explanation for these results is that perhaps the Irish living in more clustered areas (which were generally more urban) had more recently arrived in the US and would then gradually move to less clustered areas over time. Table 5 does show that the more clustered Irish immigrants were younger and had lived in the US almost five years less than those Irish immigrants who lived in less clustered areas. Notwithstanding this possible explanation, it would appear that geographic clustering did in fact have a significant effect on the assimilation of Irish immigrants in the US in the late nineteenth century. Those Irish immigrants who lived in less geographically clustered areas differed significantly from those who lived in more clustered areas across a range of socio-economic characteristics. And in virtually all of these characteristics, they also more closely resembled the native born, 
reflecting a greater degree of assimilation. ${ }^{12}$ These results support the views of Chiswick (2002), Borjas (1999) and Light and Isralowitz (1996), who argue that geographic clustering delays immigrant assimilation.

\footnotetext{
${ }^{12}$ To control for the potential influence of an immigrant living in an urban area on these results, I also generated the summary statistics presented in Table 5 including only those Irish immigrants who lived in urban areas. The purpose of this analysis was to examine whether the differences which exist in Table 5 may have reflected wider differences in socio-economic conditions between rural and urban areas in this timeframe. The results showed that although the differences between the above and below average clustered groups did narrow slightly when restricted to a comparison of urban populations, they were still statistically significant at the $1 \%$ level in every category with the exception of spouse literacy.
} 
Table 5

Summary Statistics of Irish Immigrants Based on Level of Geographic Clustering relative to Native Born

\section{Variable}

Observations

Age

Age at Marriage

Years in US

Rural Status

Home Ownership

Literacy

Read and write English

Read or write only

Spouse Fertility

Avg. Children Ever Born

Avg. Children Surviving

Implied Mortality Rate

Spouse Age

Spouse Age at Marriage

Spouse Birthplace

Ireland

Other Foreign Country

US

Spouse Literacy

Read and write English

Read or write only

Spouse in workforce
Above Avg.

13,552

42.1 years $* * *$

27.0 years $* * *$

22.9 years $* * *$

$12.8 \% * * *$

$24.2 \% * * *$

$93.4 \% * * *$

$1.2 \%$

$5.4 * * *$

$4.1^{* * *}$

$24.4 \%$

40.0 years $* * *$

23.7 years $* * *$

$74.7 \%$ ***

$6.1 \% * * *$

$19.2 \% * * *$

$90.2 \%$

$2.1 \%$

$3.0 \% * * *$
Below Avg.

13,170

46.0 years

27.9 years

27.8 years

$36.0 \%$

$46.9 \%$

$91.6 \%$

$1.8 \%$

5.9

4.7

$21.1 \%$

42.9 years

23.4 years

$53.5 \%$

$9.6 \%$

$37.0 \%$

$89.9 \%$

$2.2 \%$

$1.8 \%$
Native Born

15,985

48.0 years

27.2 years

N.A.

$74.7 \%$

$60.2 \%$

$94.0 \%$

$1.5 \%$

5.3

4.4

$16.7 \%$

42.8 years

22.5 years

$0.4 \%$

$2.7 \%$

$96.9 \%$

93.6\%

$1.7 \%$

$2.3 \%$

***Differences between the individuals in the two Irish samples are significant at the 1, 5 and $10 \%$ levels, respectively, using a t test for age and fertility variables, and the chi squared test of independence for the remaining variables. 


\section{Geographic clustering and occupational mobility}

In order to measure occupational mobility, it is necessary to create a framework in which to evaluate occupational levels and changes in those levels over time. As noted by Sobek (1996), “our understanding of historical social structure and where people fit in is bound up with the interpretation of occupations.”13 Thernstrom (1973) argued that the measurement of occupational mobility "requires a specification of the broad occupational categories that may be considered socially distinct, and a definition of which jobs fit in which category." ${ }^{14} \mathrm{He}$ noted that such a specification is not straightforward, requires flexibility, and is subject to change over time. In creating occupational categories for the late nineteenth century, I have drawn on Thernstrom's studies $(1964,1973)$. I have created six occupational categories (High White Collar, Low White Collar, Farmer, Skilled, Semi-skilled and Unskilled). The primary change I have made to Thernstrom's approach is to explicitly break out the results for farmers into a separate category. As Thernstrom had researched primarily urban workers in his ground breaking studies of Newburyport and Boston, Massachusetts, he had included farmers as part of the low white collar category and had not chosen to show them as a separate group. ${ }^{15}$ As my sample includes a higher percentage of farmers, I found that separating them into their own group was critical to assessing their role in the results of my occupational analysis.

The results presented in Table 6 demonstrate that geographic clustering had a significant impact on the occupations of Irish immigrants in this timeframe. Those Irish immigrants who

\footnotetext{
${ }^{13}$ Matthew Sobek, "Work, Status and Income - Men in the American Occupational Structure since the Late Nineteenth Century”, Social Science Review 20:2 (summer 1996), p. 170.

14 Thernstrom (1973), p 46.

${ }^{15}$ In creating the farmer category, I specifically excluded workers who were classified in the census data as farm labourers. Labourers who worked on farms were classified as unskilled. The farmer category is designed to capture only those individuals who either owned or managed farms.
} 
lived in above average clustered areas were less likely to be in the white collar categories and in farming, and were more likely to be in semi- and un-skilled work. We find that only $15.4 \%$ of those Irish who lived in above average clustered counties were engaged in white collar work or in farming, versus a figure of $30.7 \%$ for the less clustered group. Similarly, almost two thirds of the more clustered Irish were engaged in semi- or un-skilled work, versus approximately 55\% for those Irish who lived in less Irish neighbourhoods. ${ }^{16}$ A limitation of this analysis is that it does not control for the influence of other socio-economic characteristics of these Irish immigrants. In order to confirm the statistical significance of these characteristics on occupational outcomes, it is necessary to undertake a regression analysis. $^{17}$

\footnotetext{
${ }^{16}$ I also created comparisons for Irish immigrants who lived in the top and bottom quartile, as well as in the top and bottom decile based on their level of geographic clustering. The occupational outcomes for these comparisons were progressively more differentiated as the degree of clustering moved from halves to quartiles to deciles. The less clustered Irish became even more likely to be in white collar work and in farming, whereas the more clustered Irish were even more likely to be in semi-and un-skilled work.

${ }^{17}$ I also controlled for the potential influence of an immigrant living in an urban area by generating the occupational mobility results presented in Table 6 including only those Irish immigrants who lived in urban areas. The results confirm those in Table 6, with the differences in occupational mobility between the two groups actually increasing slightly in the white collar and skilled categories.
} 
Table 6

Irish Immigrant Occupational Groupings in 1900

Based on Level of Geographic Clustering

\section{Above average clustered Irish}

$\begin{array}{llll} & \text { No. } & \% & \text { Cum \% } \\ \text { High WC } & 944 & 6.97 & 6.97 \\ \text { Low WC } & 931 & 6.87 & 13.84 \\ \text { Farmer } & 212 & 1.56 & 15.40 \\ \text { Skilled } & 2,365 & 17.45 & 32.85 \\ \text { Semi-skilled } & 4,119 & 30.39 & 63.25 \\ \text { Unskilled } & 4,981 & 36.75 & 100.00 \\ & & & \\ \text { Total } & 13,552 & 100.00 & \end{array}$

Below average clustered Irish

$\begin{array}{llll} & \text { No. } & \% & \text { Cum \% } \\ \text { High WC } & 1,203 & 9.13 & 9.13 \\ \text { Low WC } & 958 & 7.27 & 16.41 \\ \text { Farmer } & 1,888 & 14.34 & 30.74 \\ \text { Skilled } & 1,861 & 14.13 & 44.87 \\ \text { Semi-skilled } & 2,937 & 22.30 & 67.18 \\ \text { Unskilled } & 4,323 & 32.82 & 100.00 \\ & & & \\ \text { Total } & 13,170 & 100.00 & \end{array}$


Table 7 presents the results of a multinomial logistic regression on the likelihood of an Irish immigrant in my sample being in one of the six occupational categories. This form of regression allows me to assess the impact of individual variables on the likelihood of being in one of these occupational categories, while controlling for the impact of other variables. ${ }^{18}$ The results in Table 7 show the marginal effects of these variables for each occupational category. With this approach, one can demonstrate the impact which these variables have on the likelihood of an Irish immigrant being in a particular occupational group. In particular, this approach allows me to observe the influence of geographic clustering on occupational outcomes, while controlling for a host of other socio-economic variables including age and years living in the US. As a result, it will allow me to reach more definitive conclusions about the specific impact of geographic clustering on occupational outcomes.

The results confirm that geographic clustering was an important factor in the occupational outcomes of Irish immigrants at the turn of the century. In every category except the unskilled, the influence of geographic clustering was statistically significant. For the high white collar category, geographic clustering was significant at the $1 \%$ confidence level and was negative, indicating that those Irish who lived in more heavily concentrated Irish counties were less likely to be in the highest occupational category in 1900 . The marginal effect output also allows us to calculate the magnitude of this effect. If we were to assume that an Irish immigrant moved from a county with no other Irish immigrants to the county in the greater Boston area with the highest percentage of Irish immigrants (12.02\%), the effect of this change in geographic clustering, holding other variables constant, would be to reduce his likelihood of being in a high white collar occupation by $2.4 \%$. While this may not sound

\footnotetext{
${ }^{18}$ Which include age, spouse age, years living in the US, duration of marriage, literacy, spouse literacy, home ownership, urban status, employment status, intermarriage, and the percent of population in the immigrant's county of residence whom were born in Ireland.
} 
significant, it represents a 30\% reduction in the share of Irish immigrants who held high white collar occupations in 1900 (Irish immigrants in this category being approximately 8\% in my sample). The results for the low white collar category were similar, with the marginal effect of geographic clustering indicating a 3.6\% reduction in the likelihood of being in a low white collar occupation. This figure represents a 51\% reduction in the share of Irish immigrants who would have held low white collar occupations. As for farming, the results indicate that the impact of geographic clustering was similar to that for the white collar categories with a $30 \%$ reduction in the share of Irish immigrants in this occupational group. The results for the farming category were also significant at the $1 \%$ confidence level. These results indicate that geographic clustering did not aid Irish immigrants in reaching the higher occupational categories in 1900, but was in fact a hindrance to advancing up the occupational ladder. In each of these occupational categories, Irish immigrants who lived in more geographically clustered counties were less likely to be employed in 1900. As for the skilled and semi-skilled categories, Irish immigrants who lived in more geographically clustered counties were more likely to work in these sectors of the workforce. The relationship between geographic clustering and working in these occupational categories in 1900 was statistically significant and positive, reflecting a $1 \%$ confidence level for the skilled worker level and a $5 \%$ confidence level for the semi-skilled category. The marginal effects calculations indicate a $2 \%$ and $8 \%$ increase in the likelihood of being in these two categories, respectively. These effects would have resulted in increases in the share of Irish immigrant workers in these categories of $15 \%$ and $32 \%$, respectively. Only in the unskilled category was the effect of geographic clustering not statistically significant. In this category, factors such as years living in the US, literacy and intermarriage were critical, in each case with the relationship being negative. Irish immigrants that were newer to the US, married to an Irish born spouse, and less literate were more likely to find themselves in unskilled work. These factors were more 
important than whether an Irish immigrant lived in a geographically clustered area for

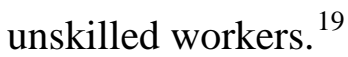

The multinomial logistic regression analysis clearly shows that Irish immigrants who lived in more ethnically clustered environments were less likely to work in the higher occupational categories, and were more likely to find employment in the skilled and semi-skilled categories. Even when the analysis was limited solely to urban workers, the results were unchanged. Returning to the literature, these results would appear to refute the views of Chiswick (2002), Portes and Rumbaut (1996) and Gordon (1964) who argue that immigrant enclaves were advantageous to immigrants seeking work in a new society. These results, which control for the influence of factors such as age, years living in the US, literacy and other factors, clearly show that for Irish immigrants in this timeframe, geographic clustering did not help them to advance up the occupational ladder.

\footnotetext{
${ }^{19}$ In further results not reported here, I also generated a multinomial logistic regression on the likelihood of an Irish immigrant being in a particular occupational category, in this case excluding farmers and those immigrants living in rural areas. The purpose of this additional regression was to examine the impact of geographic clustering solely on urban workers, where most Irish immigrants lived and where their networks were likely to have been strongest. The results of this regression support the conclusion that geographic clustering did not aid Irish immigrants in reaching the highest occupational categories (i.e. high and low white collar), but in fact had a negative relationship with these two categories. Geographic clustering did have a positive effect on Irish immigrants in the skilled and semi-skilled categories, but not for the unskilled. All of the results were statistically significant.
} 
Table 7

Multinomial Logistic Regression Results for Occupational Groups

\begin{tabular}{|c|c|c|c|c|c|}
\hline High WC & $\mathrm{dy} / \mathrm{dx}$ & std err & $\mathrm{z}$ & $\mathrm{P}>|\mathrm{z}|$ & $\mathrm{x}$ \\
\hline age & 0.003 & 0.000 & 6.28 & 0.000 & 45.31 \\
\hline spouse age & -0.001 & 0.000 & -2.00 & 0.046 & 41.39 \\
\hline yrsinUS & 0.001 & 0.000 & 5.04 & 0.000 & 26.75 \\
\hline yrsmarried & -0.001 & 0.000 & -3.68 & 0.000 & 17.85 \\
\hline literacy* & 0.053 & 0.006 & 8.24 & 0.000 & 0.94 \\
\hline spouse literacy* & 0.044 & 0.007 & 6.49 & 0.000 & 0.92 \\
\hline home* & 0.050 & 0.005 & 10.07 & 0.000 & 0.39 \\
\hline urban* & 0.021 & 0.004 & 4.62 & 0.000 & 0.77 \\
\hline employed* & 0.089 & 0.004 & 23.38 & 0.000 & 0.77 \\
\hline intermarried* & 0.047 & 0.005 & 9.31 & 0.000 & 0.36 \\
\hline \% Irish & -0.002 & 0.001 & -2.74 & 0.006 & 5.53 \\
\hline Low WC & $\mathrm{dy} / \mathrm{dx}$ & std err & $\mathrm{z}$ & $\mathrm{P}>|\mathrm{z}|$ & $\mathrm{x}$ \\
\hline age & 0.001 & 0.000 & 1.40 & 0.162 & 45.31 \\
\hline spouse age & -0.001 & 0.000 & -2.39 & 0.017 & 41.39 \\
\hline yrsinUS & 0.000 & 0.000 & 1.63 & 0.103 & 26.75 \\
\hline yrsmarried & -0.000 & 0.000 & -0.52 & 0.605 & 17.85 \\
\hline literacy* & 0.054 & 0.006 & 9.22 & 0.000 & 0.94 \\
\hline spouse literacy* & 0.035 & 0.007 & 4.73 & 0.000 & 0.92 \\
\hline home* & 0.001 & 0.004 & 0.34 & 0.732 & 0.39 \\
\hline urban* & 0.024 & 0.004 & 5.50 & 0.000 & 0.77 \\
\hline employed* & 0.071 & 0.004 & 18.74 & 0.000 & 0.77 \\
\hline intermarried* & 0.046 & 0.005 & 9.22 & 0.000 & 0.36 \\
\hline \% Irish & -0.003 & 0.001 & -4.08 & 0.000 & 5.53 \\
\hline Farmer & $\mathrm{dy} / \mathrm{dx}$ & std err & $\mathrm{z}$ & $\mathrm{P}>|\mathrm{z}|$ & $\mathrm{x}$ \\
\hline age & 0.000 & 0.000 & 4.17 & 0.000 & 45.31 \\
\hline spouse age & 0.000 & 0.000 & 0.51 & 0.608 & 41.39 \\
\hline yrsinUS & 0.000 & 0.000 & 3.75 & 0.000 & 26.75 \\
\hline yrsmarried & -0.000 & 0.000 & -0.97 & 0.334 & 17.85 \\
\hline literacy* & 0.002 & 0.001 & 2.10 & 0.036 & 0.94 \\
\hline spouse literacy* & 0.002 & 0.001 & 1.22 & 0.224 & 0.92 \\
\hline home* & 0.012 & 0.001 & 8.45 & 0.000 & 0.39 \\
\hline urban* & -0.148 & 0.009 & -17.39 & 0.000 & 0.77 \\
\hline employed* & 0.015 & 0.001 & 11.27 & 0.000 & 0.77 \\
\hline intermarried* & 0.001 & 0.001 & 1.62 & 0.106 & 0.36 \\
\hline$\%$ Irish & -0.002 & 0.000 & -10.87 & 0.000 & 5.53 \\
\hline
\end{tabular}

$\left.{ }^{*}\right) \mathrm{dy} / \mathrm{dx}$ is for discrete change of dummy variable from 0 to 1 


\begin{tabular}{|c|c|c|c|c|c|}
\hline Skilled & $\mathrm{dy} / \mathrm{dx}$ & std err & $\mathrm{z}$ & $\mathrm{P}>|\mathrm{z}|$ & $\mathrm{x}$ \\
\hline age & -0.002 & 0.001 & -2.29 & 0.022 & 45.31 \\
\hline spouse age & 0.000 & 0.001 & 0.25 & 0.804 & 41.39 \\
\hline yrsinUS & 0.003 & 0.000 & 7.63 & 0.000 & 26.75 \\
\hline yrsmarried & 0.000 & 0.001 & 0.44 & 0.657 & 17.85 \\
\hline literacy* & 0.138 & 0.010 & 13.91 & 0.000 & 0.94 \\
\hline spouse literacy* & 0.088 & 0.011 & 7.78 & 0.000 & 0.92 \\
\hline home* & 0.004 & 0.007 & 0.59 & 0.555 & 0.39 \\
\hline urban* & 0.084 & 0.008 & 11.26 & 0.000 & 0.77 \\
\hline employed* & -0.033 & 0.008 & -4.36 & 0.000 & 0.77 \\
\hline intermarried* & 0.061 & 0.008 & 8.06 & 0.000 & 0.36 \\
\hline \% Irish & 0.002 & 0.001 & 1.97 & 0.049 & 5.53 \\
\hline Semi-skilled & $\mathrm{dy} / \mathrm{dx}$ & std err & $\mathrm{z}$ & $\mathrm{P}>|\mathrm{z}|$ & $\mathrm{x}$ \\
\hline age & -0.003 & 0.001 & -3.11 & 0.002 & 45.31 \\
\hline spouse age & -0.001 & 0.001 & -1.06 & 0.289 & 41.39 \\
\hline yrsinUS & 0.001 & 0.001 & 2.12 & 0.034 & 26.75 \\
\hline yrsmarried & 0.000 & 0.001 & 0.36 & 0.717 & 17.85 \\
\hline literacy* & 0.006 & 0.018 & 0.33 & 0.743 & 0.94 \\
\hline spouse literacy* & -0.033 & 0.017 & -2.03 & 0.043 & 0.92 \\
\hline home* & 0.005 & 0.009 & 0.59 & 0.555 & 0.39 \\
\hline urban* & -0.002 & 0.010 & -0.19 & 0.847 & 0.77 \\
\hline employed* & 0.060 & 0.009 & 6.87 & 0.000 & 0.77 \\
\hline intermarried* & 0.017 & 0.009 & 1.94 & 0.052 & 0.36 \\
\hline \% Irish & 0.007 & 0.001 & 5.27 & 0.000 & 5.53 \\
\hline Un-skilled & $\mathrm{dy} / \mathrm{dx}$ & std err & $\mathrm{z}$ & $\mathrm{P}>|\mathrm{z}|$ & $\mathrm{x}$ \\
\hline age & 0.001 & 0.001 & 0.96 & 0.339 & 45.31 \\
\hline spouse age & 0.003 & 0.001 & 2.89 & 0.004 & 41.39 \\
\hline yrsinUS & -0.006 & 0.001 & -11.47 & 0.000 & 26.75 \\
\hline yrsmarried & 0.001 & 0.001 & 1.28 & 0.201 & 17.85 \\
\hline literacy* & -0.253 & 0.019 & -13.61 & 0.000 & 0.94 \\
\hline spouse literacy* & -0.135 & 0.017 & -8.11 & 0.000 & 0.92 \\
\hline home* & -0.073 & 0.009 & -8.04 & 0.000 & 0.39 \\
\hline urban* & 0.020 & 0.011 & 1.89 & 0.058 & 0.77 \\
\hline employed* & -0.202 & 0.010 & -21.17 & 0.000 & 0.77 \\
\hline intermarried* & -0.172 & 0.009 & -20.00 & 0.000 & 0.36 \\
\hline \% Irish & -0.002 & 0.001 & -1.58 & 0.114 & 5.53 \\
\hline
\end{tabular}

$\left.{ }^{*}\right) \mathrm{dy} / \mathrm{dx}$ is for discrete change of dummy variable from 0 to 1 


\section{Occupational benefits of geographic clustering?}

One final question to be addressed is whether the more geographically clustered Irish were disproportionately represented in certain occupations. In the literature, McCaffrey (1996) and McKivigan and Robertson (1996) argue that nineteenth century Irish immigrants benefited from the networking opportunities and support systems which had developed in cities such as New York which had large concentrations of Irish immigrants. McCaffrey (1996) argues that the Irish were able to make occupational advances in local government, trade unions and the Catholic Church, ${ }^{20}$ while McKivigan and Robertson (1996) argue that the Irish in New York City had particular success in obtaining work "in city government jobs for policemen, firefighters, rapid transit workers and school teachers.” McKivigan and Robertson (1996) also argue that by 1900, significant numbers of the city’s Irish had moved up into the ranks of professionals and entrepreneurs.” ${ }^{21}$ Chiswick (2002), Portes and Rumbaut (1996) and Gordon (1964) also argue that ethnic enclaves provided significant advantages for new immigrants and immigrant entrepreneurs. These potential benefits of living in an immigrant enclave can be tested against the evidence which I have assembled using my sample data. If this literature is correct, I should find evidence that Irish immigrants benefited from geographic clustering and were able to gain access to jobs in areas such as city government (government workers, policemen, firemen, public transit workers), in the Roman Catholic church, as well as in jobs where trade union ties were important in this timeframe (longshoremen, railroad, mining, lumbermen). This literature implies that Irish immigrants living in these enclaves would have had an advantage in the employment market versus Irish immigrants who did not live in such areas. Using my sample data, I examine these arguments.

\footnotetext{
${ }^{20}$ McCaffrey (1996), p.222.

${ }^{21}$ McKivigan and Robertson (1996), p. 312.
} 
I have calculated the average level of geographic clustering for each occupation held by an Irish immigrant in 1900. I have then indexed this average to the highest level of clustering in any county in my sample in 1900 (Suffolk County, Massachusetts). This resultant index thus shows the average level of geographic clustering for each occupation as a ratio of the highest concentration of Irish immigrants in a county in this time period. Appendix 1 presents the complete list of occupations held by Irish immigrants in my sample, along with the number of immigrants who held this occupation and the clustering ratio described above. The list is sorted from those occupations with the lowest average level of geographic clustering to the highest. Table 8 shows the average clustering ratio for each occupational category. Table 9 provides these results for a selection of notable occupations. There are several conclusions that can be drawn from this data. First of all, as my prior analyses in this paper have shown, geographic clustering appears to have an inverse relationship with occupational category. The ratio of geographic clustering is higher for the lower occupational categories than it is for the white collar or farming categories. In terms of particular occupations, white collar jobs such as managers, teachers, physicians and surgeons, lawyers and judges, officials and administrators all have relatively low clustering ratios. Interestingly, clergymen also have a low ratio at just .292. This result would suggest that those Irish immigrants who entered the church did not live in more clustered areas in $1900 .{ }^{22}$ What is also interesting is that there are many jobs that were more likely to be unionised, such as lumbermen, railroad repairmen, and mine workers, where the clustering ratio is also relatively low. This result likely reflects the fact these occupations frequently required workers to live in the more remote regions of the country where the mines, railroads and forests were located and/or being constructed. Though as we have seen there were some remote counties where Irish immigrants were highly concentrated (such as Storey, Nevada, and Silver Bow and Deer Lodge, Montana), these

\footnotetext{
${ }^{22}$ What this data does not show, unfortunately, is where the Irish immigrants who entered the clergy were living at the time that they joined the church. It may have been the case that some of these immigrants may have lived in more clustered areas when they joined the church, and were later assigned to parishes in less clustered areas.
} 
results would indicate that, for the most part, Irish immigrants working in these unionised occupations did not live in more clustered areas. ${ }^{23}$ With respect to local government related jobs such as government workers, policemen, firemen, and public transit workers, the results are also instructive. Firemen, policemen and motormen have clustering ratios that would place them near the middle of the distribution, reflecting that they did not live, on average, in particularly highly clustered counties. Public officials and administrators actually had a relatively low ratio of .329 while teachers had an even lower ratio at just .190. The primary occupational area where one does find consistently high clustering ratios was in textiles (spinners, weavers, dyers, loom fixers) as well as in urban service occupations such as waiters and waitresses, and taxicab drivers. In the latter case, this pattern may reflect local demand for services from other Irish immigrants.

This analysis only serves to reinforce my prior conclusions that the occupational levels of Irish immigrants in this time frame were inversely related to their level of geographic clustering. What these results also demonstrate is that the benefits of living in an area with a high concentration of Irish immigrants as described by McCaffrey (1996) and McKivigan and Robertson (1996) may not have been as significant as these authors have suggested. I find scarce evidence that geographic clustering led to greater employment opportunities in local government and unionised work. In fact, the bulk of evidence presented herein would refute that claim. One could argue that these results do not undermine the idea that Irish immigrants could have initially benefited from living in immigrant enclaves, and that as they spent more time living in the US, they migrated towards less ethnically concentrated areas of the country. However, these results might also support the view that living in a more ethnically concentrated community, though it may have improved the initial starting position of Irish

\footnotetext{
${ }^{23}$ Among occupations more likely to have been unionised in 1900, only longshoremen had a relatively high clustering ratio.
} 
immigrants in America, came at the expense of slower subsequent assimilation and reduced occupational mobility. In my analysis, I find very limited support for the view that living in an area with a high concentration of Irish immigrants enhanced the occupational outcomes of Irish immigrants versus those that lived in less geographically clustered areas. 
Table 8

Irish Immigrant Occupational Levels Based on Clustering Index

Occupational Level

High White Collar

Low White Collar

Farmer

Skilled

Semi-skilled

Unskilled

\section{Clustering Ratio}

.407

.450

.183

.483

.498

.479

Table 9

Selected List of Irish Immigrant Occupations Based on Clustering Index

\section{Occupation}

Teachers

Managers and superintendents

Physicians and surgeons

Clergymen

Lawyers and judges

Officials and administrators

Lumbermen

Mine operatives

Locomotive engineers

Locomotive firemen

Brakemen, railroad

Firemen

Policemen and detectives

Motormen

Spinners

Weavers

Taxicab drivers and chauffeurs

Dyers

Waiter and waitresses
Occupational Level

High White Collar

High White Collar

High White Collar

High White Collar

High White Collar

High White Collar

Unskilled

Semi-skilled

Skilled

Semi-skilled

Semi-skilled

Semi-skilled

Semi-skilled

Semi-skilled

Semi-skilled

Semi-skilled

Semi-skilled

Semi-skilled

Semi-skilled

\section{Clustering Ratio}

.190

.281

.284

.292

.314

.329

.166

.301

.302

.310

.394

.421

.486

.493

.575

.582

.592

.613

.687 


\section{Conclusion}

In this paper, I have demonstrated that geographic clustering did exist for Irish immigrants in late nineteenth century America. Irish immigrants were primarily drawn to the large metropolitan areas of the Northeast, reflecting the importance of these areas as points of entry to the US, as well as major centres for employment for new immigrants. In smaller numbers, Irish immigrants also concentrated in certain Western regions to work in the mining, railroad and farming industries. The settlement choices of earlier cohorts of Irish immigrants also seem to have been important for the late nineteenth century Irish. Thus it would appear that proximity to ports of entry, job opportunities, and the settlement choices of earlier groups of Irish immigrants were critical to the geographic location of the Irish immigrants at the turn of the century.

What is also clear from the analysis presented in this paper is that geographic clustering directly impacted the degree of assimilation and occupational mobility of Irish immigrants in this timeframe. Higher levels of geographic clustering were associated with both lower degrees of assimilation and lower occupational outcomes. Irish immigrants who lived in less geographically clustered areas much more closely resembled the native born. In addition, those Irish who lived in more heavily concentrated Irish counties were less likely to be in the higher occupational categories in 1900, and more likely to be in less skilled work. Geographic clustering also did not appear to assist Irish immigrants in gaining preferential access to jobs in city government, the Roman Catholic Church, or where trade union ties were important. The benefits of geographic clustering in the job market do not appear to have existed for Irish immigrants in the late nineteenth century, and this research provides further support for the argument that such clustering delays the assimilation process. 


\section{Appendix 1 \\ List of Irish Immigrant Occupations Based on Clustering Index}

No. of

Observations Occupation

1 Officials, lodge, society, union, etc.

1 Apprentices, printing trades

3 Opticians and lens grinders and polishers

1 Counter and fountain workers

4 Postmasters

1 Blasters and powdermen

1 Apprentices, other specified trades

7 Inspectors, scalers, and graders log and lumber

1 Dancers and dancing teachers

1 Architects

48 Lumbermen, raftsmen, and woodchoppers

1 Technicians

2094 Farmers (owners and tenants)

39 Teachers

1 Plumbers and pipe fitters apprentice

24 Railroad and car shop-mechanics and repairmen

10 Religious workers

1 Credit men

6 Farm managers

19 Buyers and shippers, farm products

3 Therapists and healers

6 Subject not specified-Professors and instructors

1 Entertainers

13 Millers, grain, flour, feed, etc

93 Managers and superintendents, building

3 Marshals and constables

35 Physicians and surgeons

133 Clergymen

1 Apprentices, metalworking trades

876 Mine operatives and labourers

112 Locomotive engineers

13 Musicians and music teachers

61 Locomotive firemen

47 Lawyers and judges

4 Photoengravers and lithographers

11 Sawyers

12 Sports instructors and officials

31 Officials and administrators, public administration

16 Baggagemen, transportation

10 Civil-Engineers

1 Photographic process workers

1 Chainmen, rodmen, and axmen, surveying

384 Foremen

7 Stenographers, typists, and secretaries

11 Telegraph operators

96 Furnacemen, smeltermen and pourers

27 Members of the armed services

706 Farm labourers, wage workers $\begin{array}{ll}\text { Occupational } & \text { Clustering } \\ \text { Level } & \text { Ratio }\end{array}$

High WC

0.005

Semi-skilled $\quad 0.009$

Low WC $\quad 0.045$

Semi-skilled $\quad 0.048$

Low WC $\quad 0.085$

Semi-skilled $\quad 0.131$

Semi-skilled $\quad 0.151$

Skilled $\quad 0.157$

Low WC $\quad 0.158$

High WC $\quad 0.166$

Unskilled $\quad 0.166$

Low WC $\quad 0.173$

Farmer $\quad 0.183$

High WC $\quad 0.190$

Semi-skilled $\quad 0.200$

Skilled $\quad 0.210$

High WC $\quad 0.237$

Low WC $\quad 0.244$

Farmer $\quad 0.248$

High WC $\quad 0.248$

Low WC $\quad 0.250$

High WC $\quad 0.253$

Low WC $\quad 0.266$

Skilled $\quad 0.268$

High WC $\quad 0.281$

Semi-skilled $\quad 0.282$

High WC $\quad 0.284$

High WC $\quad 0.292$

Semi-skilled $\quad 0.300$

Semi-skilled $\quad 0.301$

Skilled $\quad 0.302$

Low WC $\quad 0.307$

Skilled $\quad 0.310$

High WC $\quad 0.314$

Skilled $\quad 0.315$

Semi-skilled $\quad 0.320$

Low WC $\quad 0.323$

High WC $\quad 0.329$

Low WC $\quad 0.338$

High WC $\quad 0.342$

Skilled $\quad 0.344$

Semi-skilled $\quad 0.344$

Low WC $\quad 0.348$

Low WC $\quad 0.357$

Low WC $\quad 0.360$

Semi-skilled $\quad 0.361$

Semi-skilled $\quad 0.363$

Unskilled $\quad 0.366$ 
6 Actors and actresses

Low WC

0.368

5 Millwrights

19 Officers, pilots, pursers and engineers, ship

Skilled

0.371

7 Veterinarians

124 Boilermakers

Low WC

0.374

66 Inspectors

9 Messengers and office boys

High WC

0.376

Skilled

0.377

Skilled

0.378

31 Linemen, servicemen, telegraph, telephone and power

Low WC

0.380

Skilled

0.380

18 Heaters, metal

15 Pharmacists

104 Brakemen, railroad

23 Mechanical-Engineers

75 Sailors and deck hands

4 Athletes

17 Boarding and lodging house keepers

Semi-skilled $\quad 0.384$

High WC $\quad 0.391$

Semi-skilled $\quad 0.394$

High WC $\quad 0.407$

Semi-skilled $\quad 0.407$

Low WC $\quad 0.408$

Semi-skilled $\quad 0.411$

Semi-skilled $\quad 0.411$

Low WC $\quad 0.413$

Draftsmen

5 Oilers and greaser, except auto

47 Firemen, fire protection

14 Inspectors, public administration

75 Insurance agents and brokers

205 Clerical and kindred workers

9 Paperhangers

2 Nurses, professional

28 Watchmen (crossing) and bridge tenders

2 Farm foremen

6 Cashiers

1636 Managers, officials, and proprietors

15 Sheriffs and bailiffs

47 Real estate agents and brokers

16 Ticket, station, and express agents

26 Deliverymen and routemen

22 Laundry and dry cleaning Operatives

409 Blacksmiths

3 Professional, technical and kindred workers

77 Bookkeepers

3 Attendants, professional and personal service

35 Barbers, beauticians, and manicurists

328 Stationary engineers

25 Rollers and roll hands, metal

370 Guards, watchmen, and doorkeepers

4 Advertising agents and salesmen

8 Photographers

8 Chemists

5 Express messengers and railway mail clerks

149 Craftsmen and kindred workers

31 Collectors, bill and account

20 Jewellers, watchmakers, goldsmiths, and silversmiths

12 Funeral directors and embalmers

84 Meat cutters, except slaughter and packing house

36 Boatmen, canalmen, and lock keepers

278 Policemen and detectives

7972 Labourers

181 Painters, construction and maintenance

Semi-skilled $\quad 0.417$

Semi-skilled $\quad 0.421$

Low WC $\quad 0.425$

Low WC $\quad 0.428$

Low WC $\quad 0.430$

Skilled $\quad 0.431$

Low WC $\quad 0.433$

Semi-skilled $\quad 0.434$

Unskilled $\quad 0.434$

Low WC $\quad 0.435$

High WC $\quad 0.437$

Semi-skilled $\quad 0.443$

Low WC $\quad 0.443$

Low WC $\quad 0.446$

Semi-skilled $\quad 0.446$

Semi-skilled $\quad 0.447$

Skilled $\quad 0.447$

High WC $\quad 0.449$

Low WC $\quad 0.450$

Semi-skilled $\quad 0.455$

Semi-skilled $\quad 0.460$

Skilled $\quad 0.463$

Skilled $\quad 0.465$

Semi-skilled $\quad 0.467$

Low WC $\quad 0.467$

Low WC $\quad 0.469$

High WC $\quad 0.470$

Low WC $\quad 0.470$

Skilled $\quad 0.470$

Low WC $\quad 0.476$

Skilled $\quad 0.478$

Low WC $\quad 0.480$

Semi-skilled $\quad 0.480$

Semi-skilled $\quad 0.484$

Semi-skilled $\quad 0.486$

Unskilled $\quad 0.487$

Skilled $\quad 0.488$ 
301 Stationary firemen

$\begin{array}{ll}\text { Semi-skilled } & 0.488 \\ \text { Unskilled } & 0.492 \\ \text { Semi-skilled } & 0.493 \\ \text { Skilled } & 0.493 \\ \text { Skilled } & 0.494 \\ \text { Skilled } & 0.495 \\ \text { Skilled } & 0.496 \\ \text { Semi-skilled } & 0.497 \\ \text { Skilled } & 0.497 \\ \text { Low WC } & 0.498 \\ \text { Low WC } & 0.499 \\ \text { Skilled } & 0.500\end{array}$

19 Fishermen and oystermen

156 Motormen, street, subway, and elevated railway

544 Carpenters

51 Tinsmiths, coppersmiths, and sheet metal workers

160 Stone cutters and stone carvers

425 Brickmasons, stonemasons, and tile setters

54 Conductors, bus and street railway

143 Tailors and tailoresses

9 Artists and art teachers

109 Conductors, railroad

268 Molders, metal

6 Dentists

2 Engravers, except engravers

5 Laundresses, private household

72 Hucksters and peddlers

46 Attendants, hospital and other institution

590 Salesmen and sales clerks

4 Charwomen and cleaners

134 Janitors and sextons

14 Upholsterers

12 Agents

32 Mail carriers

332 Machinists

128 Plasterers

61 Cooks, except private household

18 Editors and reporters

7 Pressmen and plate printers, printing

15 Service workers, except private household

102 Private household workers

6 Cement and concrete finishers

298 Gardeners, except farm, and groundskeepers

17 Practical nurses

1657 Operative and kindred workers

269 Bartenders

188 Plumbers and pipe fitters

44 Filers, grinders, and polishers, metal

15 Housekeepers and stewards, except private household

58 Compositors and typesetters

256 Longshoremen and stevedores

14 Bookbinders

92 Bakers

20 Structural metal workers

48 Electricians

51 Shipping and receiving clerks

7 Pattern and model makers, except paper

38 Mechanics and repairmen

943 Truck and tractor drivers

51 Painters, except construction or maintenance

46 Spinners, textile

168 Porters

160 Weavers, textile

2 Auctioneers

16 Bus drivers

High WC $\quad 0.502$

Skilled $\quad 0.503$

Semi-skilled $\quad 0.505$

Low WC $\quad 0.506$

Semi-skilled $\quad 0.507$

Low WC $\quad 0.511$

Semi-skilled $\quad 0.515$

Semi-skilled $\quad 0.518$

Skilled $\quad 0.518$

Low WC $\quad 0.519$

Low WC $\quad 0.521$

Skilled $\quad 0.521$

Skilled $\quad 0.523$

Semi-skilled $\quad 0.525$

High WC $\quad 0.527$

Skilled $\quad 0.527$

Semi-skilled $\quad 0.527$

Semi-skilled $\quad 0.529$

Skilled $\quad 0.531$

Unskilled $\quad 0.532$

Semi-skilled $\quad 0.533$

Semi-skilled $\quad 0.535$

Semi-skilled $\quad 0.536$

Skilled $\quad 0.539$

Semi-skilled $\quad 0.548$

Semi-skilled $\quad 0.550$

Skilled $\quad 0.552$

Unskilled $\quad 0.552$

Skilled $\quad 0.554$

Skilled $\quad 0.560$

Skilled $\quad 0.565$

Skilled $\quad 0.567$

Low WC $\quad 0.569$

Skilled $\quad 0.570$

Skilled $\quad 0.571$

Semi-skilled $\quad 0.572$

Semi-skilled $\quad 0.574$

Semi-skilled $\quad 0.575$

Semi-skilled $\quad 0.575$

Semi-skilled $\quad 0.582$

Low WC $\quad 0.586$

Semi-skilled $\quad 0.587$ 


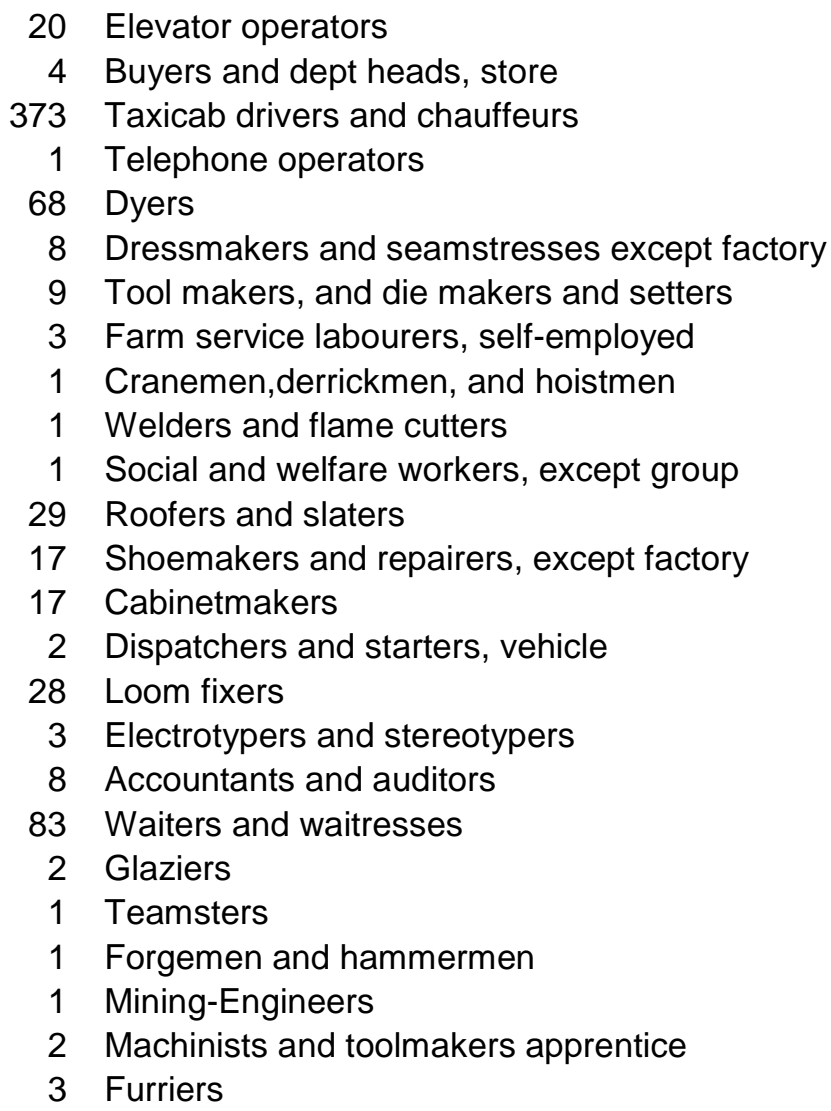

$\begin{array}{ll}\text { Semi-skilled } & 0.590 \\ \text { High WC } & 0.590 \\ \text { Semi-skilled } & 0.592 \\ \text { Low WC } & 0.595 \\ \text { Semi-skilled } & 0.598 \\ \text { Semi-skilled } & 0.613 \\ \text { Skilled } & 0.614 \\ \text { Unskilled } & 0.615 \\ \text { Skilled } & 0.633 \\ \text { Semi-skilled } & 0.633 \\ \text { High WC } & 0.641 \\ \text { Skilled } & 0.649 \\ \text { Skilled } & 0.654 \\ \text { Skilled } & 0.668 \\ \text { Low WC } & 0.673 \\ \text { Skilled } & 0.675 \\ \text { Skilled } & 0.678 \\ \text { Low WC } & 0.684 \\ \text { Semi-skilled } & 0.687 \\ \text { Skilled } & 0.720 \\ \text { Skilled } & 0.725 \\ \text { Skilled } & 0.725 \\ \text { High WC } & 0.725 \\ \text { Semi-skilled } & 0.725 \\ \text { Skilled } & 0.857\end{array}$

Total 26,722 


\section{References}

Ran Abramitsky, Leah Platt Boustan and Katherine Erickson, "Europe’s Tired, Poor, Huddled Masses: Self-Selection and Economic Outcomes in the Age of Mass Migration”, NBER Working Paper No. 15684 (January, 2010).

George J. Borjas, Heaven’s Door (Princeton: Princeton University Press, 1999).

Barry R. Chiswick, “Do Enclaves Matter in Immigrant Adjustment?”, Discussion Paper No. 449, The Institute for the Study of Labor (2002).

David M. Cutler, Edward L. Glaeser and Jacob L. Vigdor, "When are Ghettos Bad? Lessons from immigrant segregation in the United States”, Journal of Urban Economics 63, 759-774. (2008).

Otis Dudley Duncan and Beverly Duncan, "A Methodological Analysis of Segregation Indexes”, American Sociological Review 20: 210-217 (1955).

Milton M. Gordon, Assimilation in American Life (New York: 1964).

Timothy J. Hatton and Andrew Leigh, "Immigrants Assimilate as Communities, not just as Individuals”, Journal of Population Economics, 24 (2011).

Historical Census Browser. The University of Virginia, Geospatial and Statistical Data Center: http://fisher.lib.virginia.edu/collections/stats/histcensus/index.html. (2004).

Ivan Light and Richard E. Isralowitz, Immigrant Entrepreneurs and Immigrant Absorption in the United States and Israel (Aldershot: 1996).

Lawrence J. McCaffrey, "Forging Forward and Looking Back”, in The New York Irish, Ronald H. Bayor and Timothy J, Meagher (eds) (Baltimore: Johns Hopkins University Press, 1996).

John R. McKivigan and Thomas J. Robertson, 'The Irish American Worker in Transition, 1877-1914” in The New York Irish, Ronald H. Bayor and Timothy J, Meagher (eds)

(Baltimore: Johns Hopkins University Press, 1996).

Alejandro Portes and Ruben G. Rumbaut, Immigrant America (Berkeley: 1996).

Steven Ruggles, J. Trent Alexander, Katie Genadek, Ronald Goeken, Matthew B. Schroeder, and Matthew Sobek. Integrated Public Use Microdata Series: Version 5.0 [Machinereadable database]. Minneapolis: University of Minnesota, 2010.

Matthew Sobek, "Work, Status and Income - Men in the American Occupational Structure since the Late Nineteenth Century”, Social Science Review 20:2 (summer 1996). 
Matthew Sobek and Lisa Dillon, "Interpreting work: Classifying occupations in the Public Use of Microdata Samples”, Historical Methods, Winter 1995, Volume 28, Number 1.

Stephan Thernstrom, Poverty and Progress - Social Mobility in a Nineteenth Century City (Cambridge: 1964).

Stephan Thernstrom, The Other Bostonians - Poverty and Progress in the American Metropolis (Cambridge: 1973). 